Brazilian Journal of Maize and Sorghum

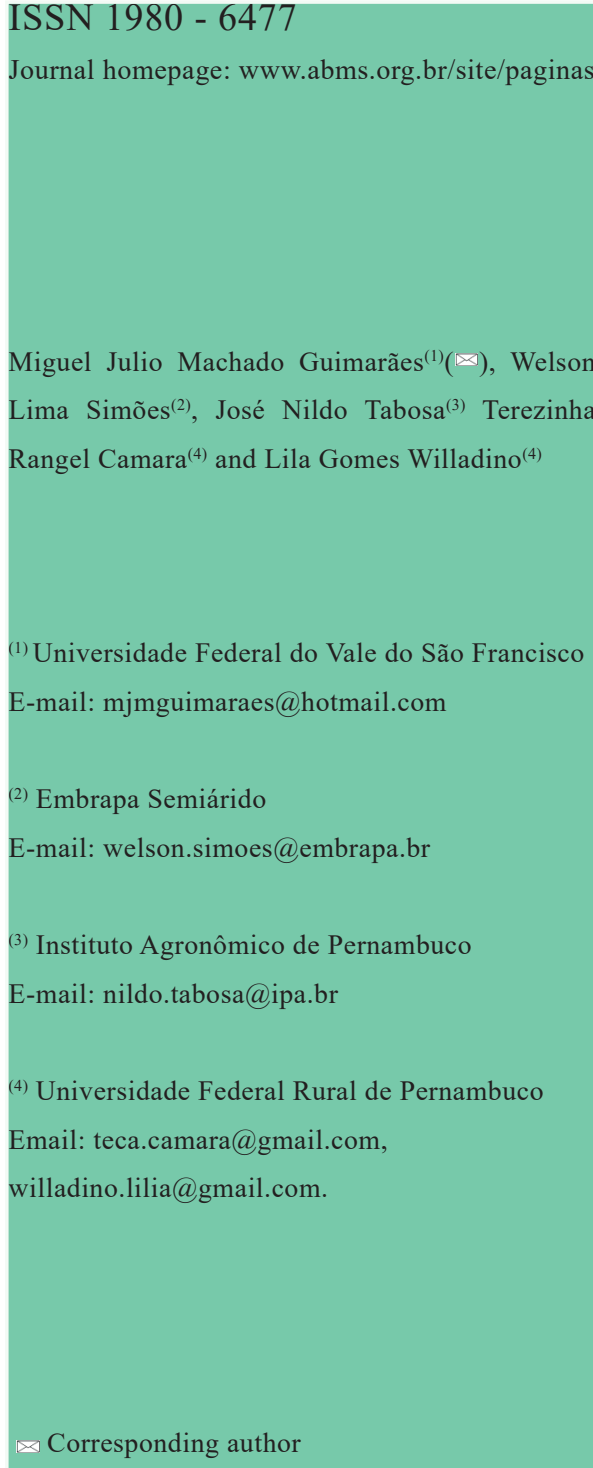

How to cite

GUIMARÃES, M. J. M.; SIMÕES, W. L; TABOSA J. N.;CAMARA, T. R.; WILLADINO, L. G. Gas exchange and enzymatic metabolism in grain sorghum varieties irrigated with saline water Revista Brasileira de Milho e Sorgo, v. 19, e1188, 2020.

\section{GAS EXCHANGE AND ENZYMATIC METABOLISM IN GRAIN SORGHUM VARIETIES IRRIGATED WITH SALINE WATER}

\begin{abstract}
The objective of this study was to evaluate the effect of irrigation water salinity on gas exchange and antioxidative system responses of grain sorghum varieties. An experiment was conducted in a greenhouse located at the headquarters of Embrapa Semiarid Agriculture, Petrolina-PE, Brazil. The experimental design was randomized blocks, in a 6 x 5 factorial scheme. Six varieties of grain sorghum irrigated with saline water with five levels of salinity were evaluated. Photosynthesis and transpiration rate, stomatal conductance, leaf temperature, intrinsic and instantaneous water use efficiency, relative water content and leaf turgor potential were evaluated, as well as the activity of the enzymes catalase, ascorbate peroxidase and superoxide dismutase, and shoot biomass production. It was observed that irrigation with saline water causes reduction in the gas exchange and water status of grain sorghum varieties. The antioxidative system was activated in the six sorghum varieties to avoid the accumulation of reactive oxygen species, and the synchronism between the enzymes led to a better response of shoot dry mass production of the Ponta Negra variety.
\end{abstract}

Keywords: salinity, Sorghum bicolor (L.). Moench, oxidative stress.

\section{TROCAS GASOSAS E METABOLISMO ENZIMÁTICO EM VARIEDADES DE SORGO GRANÍFERO IRRIGADO COM ÁGUA SALINA}

Resumo - O objetivo do trabalho foi avaliar o efeito da salinidade da água de irrigação nas trocas gasosas e nas respostas do sistema antioxidativo de variedades de sorgo granífero. Para isto, foi conduzido um ensaio em casa de vegetação localizada na sede da Embrapa Semiárido, Petrolina-PE. O delineamento experimental foi o de blocos casualizados, em esquema fatorial $6 \times 5$. Foram avaliadas seis variedades de sorgo granífero irrigados com água salina com cinco níveis de salinidade. Foram avaliadas as variáveis taxa de fotossíntese e transpiração, condutância estomática, temperatura foliar, eficiência intrínseca e instantânea do uso da água, teor relativo de água e potencial de turgor das folhas, bem como a atividade das enzimas catalase, ascorbato peroxidase e superóxido dismutase, e a produção de biomassa da parte aérea. Observou-se que a irrigação com água salina provoca redução nas trocas gasosas e no estado hídrico das variedades de sorgo granífero. O sistema antioxidativo foi ativado nas seis variedades de sorgo para evitar o acúmulo de espécies reativas de oxigênio, sendo que o sincronismo entre as enzimas refletiu numa melhor resposta de produção de massa seca da parte aérea da variedade Ponta Negra.

Palavras-chave: salinidade, Sorghum bicolor (L.). Moench, estresse oxidativo. 
Salt stress is one of the environmental factors that most limit the production of plant species in the most diverse environments. In this context, the use of production strategies that reduce the effects of salinity on agricultural crops is imperative for a successful production. Among the main production strategies in saline environment, the use of stress-tolerant crops stands out.

Sorghum (Sorghum bicolor (L) Moench) is a typical warm climate crop with xerophilic characteristics, C4 metabolism, low requirement in terms of soil fertility, and tolerance/resistance to various abiotic factors. Its great genetic variability enables different responses when subjected to salt stress (Tabatabaei and Anagholi, 2012). These are reflected in physiological variables (stomatal conductance, transpiration rate and photosynthesis) (Freire et al., 2014), biometric variables (height, leaf area, biomass production) (Costa et al., 2019; Guimarães et al., 2019), and biochemical variables (osmoregulatory solutes, antioxidant enzymes) (Barbosa et al., 2014; Coelho et al., 2018).

Under saline conditions, changes in metabolism often cause a secondary stress, oxidative stress, which results from increased production and accumulation of reactive oxygen species (ROS) in cellular metabolism. The main species produced include the radicals superoxide $\left(\mathrm{O}_{2}^{-*}\right)$, hydrogen peroxide $\left(\mathrm{H}_{2} \mathrm{O}_{2}\right)$, hydroxyl radical $\left(\mathrm{OH}^{\circ}\right)$ and singlet oxygen $\left({ }^{1} \mathrm{O}_{2}\right)$ (Barbosa et al., 2014).

As mechanisms of defense against salt stress, plants have developed an antioxidative defense complex formed by antioxidant enzymes and metabolites. The ability to activate the anti-oxidative defense mechanism is critical to prevent damage caused by extreme oxidative stress (Barbosa et al., 2014; Gill \& Tuteja, 2010). Among the various enzymes that act in this system, superoxide dismutase (SOD), catalase (CAT) and ascorbate peroxidase (APX) stand out. According to Gill \& Tuteja (2010), SOD is considered the first line of defense against ROS, being responsible for the dismutation of the superoxide radical $\left(\mathrm{O}_{2}{ }^{-}\right)$to form hydrogen peroxide $\left(\mathrm{H}_{2} \mathrm{O}_{2}\right)$ and molecular oxygen $\left(\mathrm{O}_{2}\right)$. CAT and APX, in turn, catalyze the conversion from $\mathrm{H}_{2} \mathrm{O}_{2}$ to water.

The objective of this study was to evaluate the effect of irrigation water salinity on gas exchange and antioxidative system responses of grain sorghum varieties.

\section{Material and Methods}

The experiment was installed in a greenhouse located at the headquarters of the Brazilian Agricultural Research Corporation, Semiarid Agriculture Unit, located in the municipality of Petrolina-PE, Brazil $\left(9^{\circ} 8^{\prime} 8.9^{\prime \prime} \mathrm{S} / 40^{\circ} 18^{\prime} 33.6^{\prime \prime} \mathrm{W}, 373 \mathrm{~m}\right)$. During the experimental period, the relative humidity and temperature inside the greenhouse averaged $69.8 \%$ and $27.1{ }^{\circ} \mathrm{C}$, with maximum and minimum values of $90 \%$ and $31.8 \%$ for relative humidity, and 39.6 and $20.2{ }^{\circ} \mathrm{C}$ for temperature, respectively.

Arandomized block design with three replicates was used. The treatments consisted of the combination of six varieties of grain sorghum (Sorghum bicolor (L.). Moench): 1011-IPA, 2502-IPA, 2564-IPA, 2600-IPA, Ponta Negra and Qualimax; and five levels of irrigation water salinity $(\mathrm{ECw})$ : 0.0, 1.5, 3.0, 6.0 and $12.0 \mathrm{dS} \mathrm{m} \mathrm{m}^{-1}$.

Plastic pots with $20 \mathrm{~L}$ capacity were filled with a 3-cm-thick layer of crushed stone at the base and 15 $\mathrm{kg}$ of soil collected in the 0-20 cm layer of an Argissolo Amarelo Distrófico latossólico (Ultisol), with sandy loam texture, with the following characteristics: EC 
$0.23 \mathrm{dS} \mathrm{m}^{-1} ; \mathrm{pH} 5.7 ; 0.7 \mathrm{cmolc} \mathrm{dm}^{-3}$ of $\mathrm{Mg} ; 1.0$ cmolc $\mathrm{dm}^{-3}$ of $\mathrm{Ca} ; 1.6$ cmolc $\mathrm{dm}^{-3}$ of $\mathrm{H}+\mathrm{Al} ; 0.33$ cmolc $\mathrm{dm}^{-3}$ of $\mathrm{K} ; 0.07$ cmolc $\mathrm{dm}^{-3}$ of $\mathrm{Na} ; 84.7 \%$ of sand, $13.5 \%$ of silt and $1.8 \%$ clay. Subsequently, five seeds of grain sorghum varieties were sown in each pot, at $2 \mathrm{~cm}$ depth. When the seedlings reached a height of $15 \mathrm{~cm}$, at 12 days after planting (DAP), thinning was performed, leaving only one plant per pot, and irrigations with and without saline solutions started.

Based on the results of soil analysis, plants received nutrient solution containing 160, 400, 210, 150,50 and $180 \mathrm{mg} \mathrm{dm}^{-3}$ of $\mathrm{N}, \mathrm{P}, \mathrm{K}, \mathrm{Ca}, \mathrm{Mg}$ and $\mathrm{S}$, respectively, and $0.81,1.33,0.15,3.66,4.0,0.1 \mathrm{mg}$ $\mathrm{dm}^{-3}$ of the micronutrients $\mathrm{B}, \mathrm{Cu}, \mathrm{Mo}, \mathrm{Mn}, \mathrm{Zn}$ and Fe. Nutrients were split into three equal portions and applied at a 25-day interval. The saline solutions were prepared from $\mathrm{NaCl}, \mathrm{CaCl} 2.2 \mathrm{H}_{2} \mathrm{O}$ and $\mathrm{MgSO}_{44} \cdot 7 \mathrm{H}_{2} \mathrm{O}$ salts, in order to obtain an equivalent $\mathrm{Na}: \mathrm{Ca}: \mathrm{Mg}$ ratio of $7: 2: 1$.

For irrigation management, weighing lysimeters were installed in all pots of one block. The lysimeters were equipped with load cells (TSD model, AEPH, $50 \mathrm{~kg}$ capacity) installed on a metal base with a device to collect excess drained water. The load cells were connected to two multiplexers (AM16/32B) linked to a datalogger (CR1000), which performed readings every 15 seconds, recording the average of this interval every 15 minutes. All lysimeters were calibrated to obtain a curve of signal readings $(\mathrm{mV})$ from the permanent wilting point to the maximum water holding capacity of the soil.

Irrigations were performed every two days, replacing the evapotranspired volume of water between irrigations in order to maintain soil moisture at the maximum water holding capacity. To avoid the accumulation of salts, a leaching fraction of $15 \%$ more than the recorded volume was added.
At 60 days after planting (DAP), the third fully expanded leaf was evaluated for photosynthesis rate $(A)$, stomatal conductance $(g s)$, transpiration $(E)$, leaf temperature $(L T)$, instantaneous water use efficiency $(A / E)$ and intrinsic water use efficiency $\left(A / g_{S}\right)$ using the portable Infrared Gas Analyzer (IRGA), Li-6400 model, fixing the artificial light at $2500 \mu \mathrm{mol} \mathrm{m} \mathrm{m}^{-2} \mathrm{~s}^{-1}$.

Plant water status was determined based on the relative water content (RWC) and turgor potential of the leaves (TuP) at 60 DAP. RWC was obtained through fresh mass (FM), turgid mass (TM) and dry mass (DM) and applied in the following formula: $\mathrm{RWC}=\{[(\mathrm{FM}-\mathrm{DM}) /(\mathrm{TM}-\mathrm{DM})] \times 100\}$. TuP measurements were obtained using a Wiltmeter, which was calibrated according to the methodology described in Aroca et al. (2016).

At 60 DAP, samples were collected from the leaf blade of the third fully expanded leaf counted from the apex to the plant collar. Leaf blade samples were immediately stored in aluminum foil envelopes and immersed in liquid nitrogen $\left(\mathrm{N}_{2}\right)$. For enzymatic analyses, $1 \mathrm{~g}$ of leaves of the grain sorghum varieties was macerated in liquid nitrogen with addition of $0.01 \mathrm{~g}$ of polyvinylpyrrolidone and $3 \mathrm{~mL}$ of extraction buffer ( $\mathrm{pH} 7.5)$ at potassium phosphate concentration of $100 \mathrm{mM}$. Then, the extract was centrifuged at $15,000 \times \mathrm{g}$ for 15 minutes at $4{ }^{\circ} \mathrm{C}$, and the supernatant was used as crude enzymatic extract.

Catalase (CAT) activity was determined in a solution containing $1390 \mu \mathrm{L}$ of $100 \mathrm{mM}$ potassium phosphate buffer, $60 \mu \mathrm{L}$ of $1.0 \mathrm{mM}$ hydrogen peroxide $\left(\mathrm{H}_{2} \mathrm{O}_{2}\right)$ and $50 \mu \mathrm{L}$ of protein extract, monitoring the decomposition of $\mathrm{H}_{2} \mathrm{O}_{2}$ for 60 seconds, through spectrophotometric readings at $240 \mathrm{~nm}$, at temperature of $25^{\circ} \mathrm{C}$ (Havir et al., 1987). Ascorbate peroxidase (APX) activity was determined as described by Nakano \& Asada (1981), by monitoring the rate of 
oxidation of ascorbate in a solution containing 650 $\mu \mathrm{L}$ of $100 \mathrm{mM}$ potassium phosphate buffer, $100 \mu \mathrm{L}$ of $5.0 \mathrm{mM}$ ascorbate, $100 \mu \mathrm{L}$ of $1.0 \mathrm{M}$ EDTA, $100 \mu \mathrm{L}$ of $1.0 \mathrm{mM} \mathrm{H}_{2} \mathrm{O}_{2}$ and $50 \mu \mathrm{L}$ of protein extract, using a spectrophotometer with wavelength at $290 \mathrm{~nm}$ at 30 ${ }^{\circ} \mathrm{C}$ for 60 seconds.

Superoxide dismutase (SOD) activity was determined in a reaction solution containing $1765 \mu \mathrm{L}$ of $85 \mathrm{mM}$ phosphate buffer, $225 \mu \mathrm{L}$ of $1 \mathrm{mM}$ nitroblue tetrazolium (NBT), $150 \mu \mathrm{L}$ of $0.1 \mathrm{mM}$ riboflavin, 780 $\mu \mathrm{L}$ of $50 \mathrm{mM}$ methionine, $30 \mu \mathrm{L}$ of $10 \mathrm{mM}$ EDTA and $50 \mu \mathrm{L}$ of protein extract. The evaluation procedures followed the methodology of Giannopolitis \& Ries (1977), with readings in spectrophotometer at 560 $\mathrm{nm}$ wavelength, and defining one SOD unit as the amount of enzyme needed to inhibit by $50 \%$ the photoreduction of NBT.

The data obtained were subjected to analysis of variance (ANOVA) in the program Sisvar 5.0, using the F test. First- and second-order regression models were used for comparisons between salinity levels when significant at $1 \%$ or $5 \%$ probability level. ScottKnott test at 0.05 probability level was adopted for comparison between varieties.

\section{Results and Discussion}

There was no significant interaction between varieties and $\mathrm{ECw}$ for the variables photosynthetic rate $(A)$, transpiration rate $(E)$, stomatal conductance $(g s)$, leaf temperature $(L T)$, instantaneous $(A / E)$ and intrinsic $(A / g s)$ water use efficiencies, relative water content (RWC) and turgor potential of leaves (TuP). These variables were influenced only by the individual effects of the varieties and levels of irrigation water salinity. On the other hand, there were significant interactions for the activity of enzymes that act on the antioxidative defense of plants: CAT, APX and SOD.

For the Qualimax variety, significant differences were observed in photosynthetic and transpiration rates and stomatal conductance, regardless of the salinity level studied, compared to the other varieties (Table 1). As for the instantaneous and intrinsic water use efficiencies, higher values were observed in the 1011-IPA variety, followed by 2502-IPA, 2564-IPA and 2600-IPA. Fernández-García et al. (2014) state that plants that have higher water use efficiency may be more tolerant to salinity due to the greater regulation of water losses and, consequently, delay in the accumulation of salts in their tissues by limiting the flow of salts to the shoots resulting from a lower transpiration rate.

The varieties 1011-IPA and 2564-IPA were the ones with the highest RWC, significantly differing from the others; however, the evaluation of leaf turgor potential showed similar responses for the varieties 1011-IPA, 2564-IPA, 2600-IPA and Ponta Negra, thus suggesting that the effect of salinity on the water status of the evaluated varieties occurs at different intensities.

Increasing levels of irrigation water salinity caused linear reductions in the variables $A, E$ and $g s$ (Figure 1A, 1B and 1C), but there was an increase in leaf temperature with the increase in $\mathrm{ECW}$ (Figure 1D). These reductions can be explained by the regulation of temperature regulation through transpiration (Taiz \& Zeiger, 2013). Therefore, stomatal closure is accompanied by reductions in $A$, $E$ and $g s$ and, consequently, increase in $L T$.

Regarding water use efficiency, there were increasing linear responses as a function of the salinity levels applied. It is worth pointing out that the higher the osmotic effect of salinity, the lower the degree of stomatal opening, leading to reductions 
in the photosynthetic rate and transpiration of plants (Silva et al., 2015). The ratio between photosynthesis and transpiration $(\mathrm{A} / \mathrm{E})$ indicates the amount of carbon fixed by the plant per unit of water lost, so the increases observed in $\mathrm{A} / \mathrm{E}$ and $\mathrm{A} / \mathrm{gs}$ are consequences of the sharper reduction in the transpiration and stomatal conductance, respectively, of the plants evaluated.

Increase in water use efficiency in plants subjected to salt stress has already been observed by several authors. Oliveira et al. (2017) observed increments in the intrinsic water use efficiency values of cowpea plants irrigated with saline water. FernándezGarcía et al. (2014) found an increase of up to $40 \%$ in henna plants (Lawsonia inermis $\mathrm{L}$ ) subjected to salinity of $150 \mathrm{mM}$ of $\mathrm{NaCl}$ (about $12 \mathrm{dS} \mathrm{m}^{-1}$ ) and associated this increase with the adaptive behavior of the crop under the salt stress applied.

It was possible to observe reductions in the variables RWC and TuP, which indicate the water status of plants (Figure 2A and 2B, respectively).
The reduction in leaf turgor may be related to the reduction in water availability caused by the increase in salt concentration. However, this reduction in the potential is not very significant when compared to the reduction observed in biomass production (Figure 5), so it can be inferred that the plants have mechanisms of tolerance to the stress.

Maintenance of cell turgor is a characteristic that can be associated with plants with greater adaptability to the saline environment because, when TuP is maintained, processes such as stomatal conductance, transpiration, $\mathrm{CO}_{2}$ assimilation and expansion of plant tissues are partially or fully maintained (Sampaio et al., 2014).

Changes were observed in the enzymatic metabolism of all varieties evaluated. The increase in $\mathrm{ECw}$ coincided, in general, with a higher activity of the antioxidant enzyme superoxide dismutase (SOD) (Figure 3). For the varieties 1011-IPA and 2502-IPA (Figure 3A and 3B), an progressive linear

Table 1. Averages of photosynthetic rate $(A)$, stomatal conductance $(g s)$, transpiration rate $(E)$, leaf temperature $(L T)$, instantaneous $(A / E)$ and intrinsic $(A / g s)$ water use efficiencies, relative water content (RWC) and turgor potential (TuP) in grain sorghum varieties irrigated with saline water.

\begin{tabular}{lcccccccc}
\hline Varieties & $\begin{array}{c}A \\
\mu \mathrm{mol} \mathrm{m} \mathrm{m} \mathrm{s}^{-1}\end{array}$ & $\begin{array}{c}\mathrm{gS} \\
\mathrm{mol} \mathrm{m}^{-2} \mathrm{~s}^{-1}\end{array}$ & $\begin{array}{c}E \\
\mathrm{mmol} \mathrm{m}{ }^{-2} \mathrm{~s}^{-1}\end{array}$ & $\begin{array}{c}L T \\
{ }^{\circ} \mathrm{C}\end{array}$ & $A / E$ & $A / g s$ & $\begin{array}{c}\mathrm{RWC} \\
\%\end{array}$ & $\begin{array}{c}\text { TuP } \\
\mathrm{kPa}\end{array}$ \\
\hline 1011-IPA & $27.77 \mathrm{~b}$ & $0.13 \mathrm{~b}$ & $3.23 \mathrm{~b}$ & $32.09 \mathrm{a}$ & $10.16 \mathrm{a}$ & $279.79 \mathrm{a}$ & $72.32 \mathrm{a}$ & $79.81 \mathrm{a}$ \\
2502-IPA & $25.62 \mathrm{~b}$ & $0.12 \mathrm{~b}$ & $2.96 \mathrm{~b}$ & $31.93 \mathrm{~b}$ & $8.35 \mathrm{~b}$ & $222.03 \mathrm{~b}$ & $65.1 \mathrm{~b}$ & $68.89 \mathrm{~b}$ \\
2564-IPA & $25.59 \mathrm{~b}$ & $0.12 \mathrm{~b}$ & $3.10 \mathrm{~b}$ & $32.2 \mathrm{a}$ & $8.37 \mathrm{~b}$ & $228.9 \mathrm{~b}$ & $67.58 \mathrm{a}$ & $78.03 \mathrm{a}$ \\
2600-IPA & $27.26 \mathrm{~b}$ & $0.14 \mathrm{~b}$ & $3.49 \mathrm{~b}$ & $32.25 \mathrm{a}$ & $8.43 \mathrm{~b}$ & $238.9 \mathrm{~b}$ & $59.47 \mathrm{c}$ & $78.03 \mathrm{a}$ \\
Ponta Negra & $25.54 \mathrm{~b}$ & $0.13 \mathrm{~b}$ & $3.41 \mathrm{~b}$ & $32.09 \mathrm{a}$ & $7.23 \mathrm{c}$ & $198.12 \mathrm{c}$ & $64.13 \mathrm{~b}$ & $73.79 \mathrm{a}$ \\
Qualimax & $30.44 \mathrm{a}$ & $0.16 \mathrm{a}$ & $4.01 \mathrm{a}$ & $31.8 \mathrm{~b}$ & $7.63 \mathrm{c}$ & $195.59 \mathrm{c}$ & $65.94 \mathrm{~b}$ & $62.64 \mathrm{~b}$ \\
\hline CV (\%) & 24.0 & 30.13 & 24.63 & 1.17 & 17.83 & 21.33 & 9.91 & 14.40 \\
\hline
\end{tabular}

*Means followed by the same letter in the columns within each variable do not differ by the Scott-Knott test at $5 \%$ probability level. 

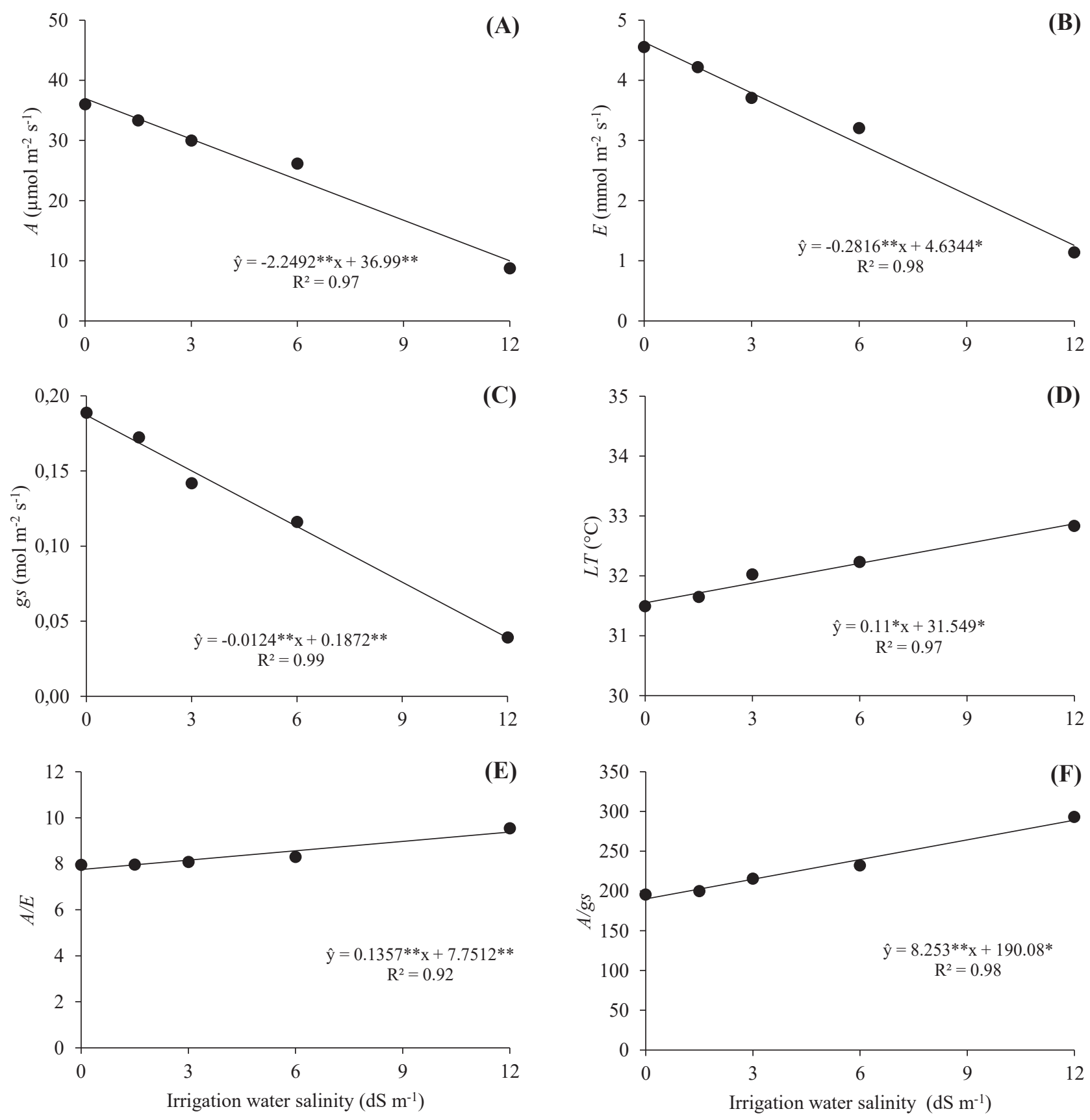

Figure 1. Photosynthetic rate $-A(\mathrm{~A})$, transpiration rate $-E(\mathrm{~B})$, stomatal conductance $-g s(\mathrm{C})$, leaf temperature $-L T(\mathrm{D})$, and instantaneous $-A / E(\mathrm{E})$ and intrinsic $-A / g s(\mathrm{~F})$ water use efficiencies in grain sorghum varieties subjected to different salinity levels. Significant regression coefficients with $\mathrm{p}<0.01$ (**) and $\mathrm{p}<0.05$ (*). 
increase was observed with the increase in $\mathrm{ECw}$, and this increase was more significant in the variety 1011 IPA, being equal to $2.43 \mathrm{U} \mathrm{gFM}^{-1} \mathrm{~min}^{-1}$ for each unit of $\mathrm{ECw}$, a value that was six times higher than that observed in 2502-IPA. The other varieties showed quadratic responses with the increase in salinity level. The highest SOD activities were observed at salinity levels of $5.19,10.93,7.77$ and $6.26 \mathrm{dS} \mathrm{m}^{-1}$ for the varieties 2564-IPA, 2600-IPA, Ponta Negra and Qualimax, respectively (Figure 3C, 3D, 3E and 3F).

Since SOD is considered the first line of defense against ROS, plants that exhibit greater activities of this enzyme have a higher potential to dismutate $\mathrm{O}_{2}{ }^{--}$and reduce its effects on metabolism. This radical is moderately reactive and has a short duration, reacts with protein and lipid molecules, and promotes membrane peroxidation, which can cause major damage to cellular metabolism (Barbosa et al.,
2014).

As for the activity of CAT and APX, which eliminate the $\mathrm{H}_{2} \mathrm{O}_{2}$ generated by SOD or other metabolic reactions, different responses can be observed between the evaluated varieties (Figure 4). 1011-IPA and 2600-IPA showed linear reduction in CAT and a quadratic behavior in APX as salinity increased, with maximum APX activity recorded at the salinity levels of 2.56 and $8.07 \mathrm{dS} \mathrm{m}^{-1}$, respectively (Figure 4A and 4D). On the other hand, the 2564-IPA variety showed a linear reduction in APX activity and a quadratic response in CAT with the increase in salinity level, with maximum activity at $7.26 \mathrm{dS} \mathrm{m}^{-1}$ (Figure 4C).

The results obtained in this study corroborate those found by several authors, who state that the physiological mechanisms of protection against abiotic stresses vary even within the same species
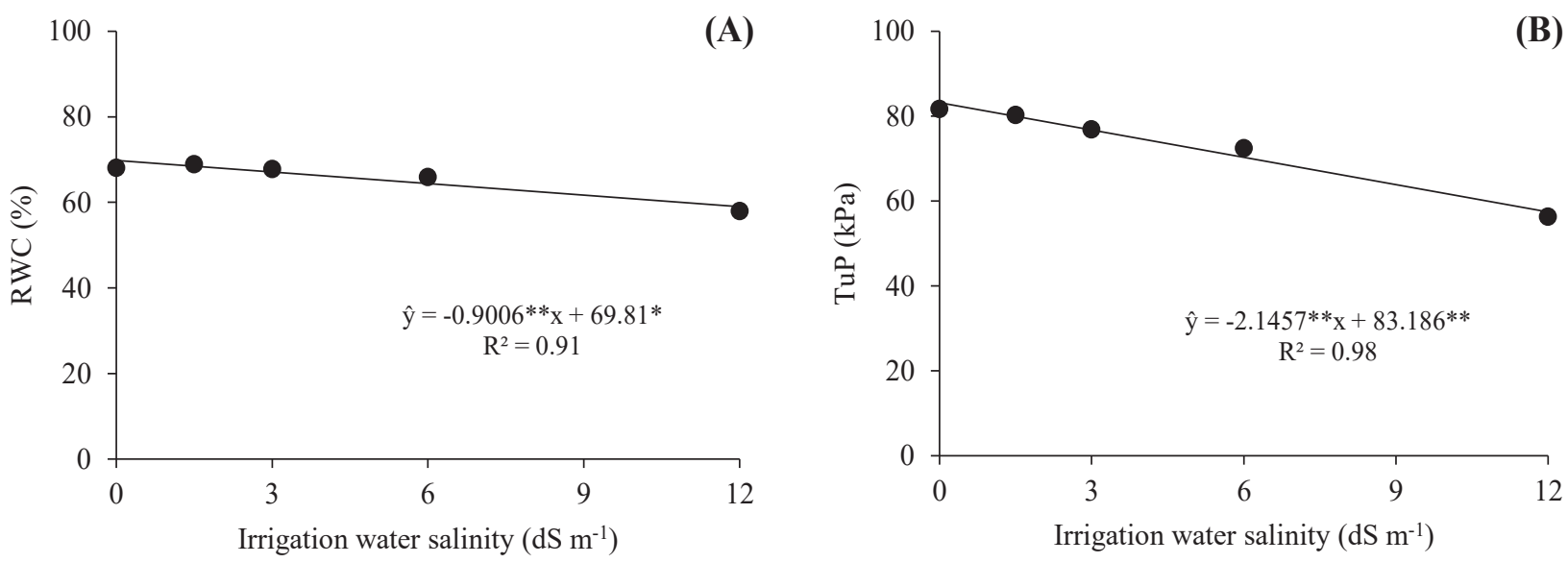

Figure 2. Relative water content (RWC) (A) and turgor potential (TuP) (B) in grain sorghum varieties subjected to different levels of irrigation water salinity. Significant regression coefficients with $\mathrm{p}<0.01$ (**) and $\mathrm{p}<0.05$ $(*)$. 

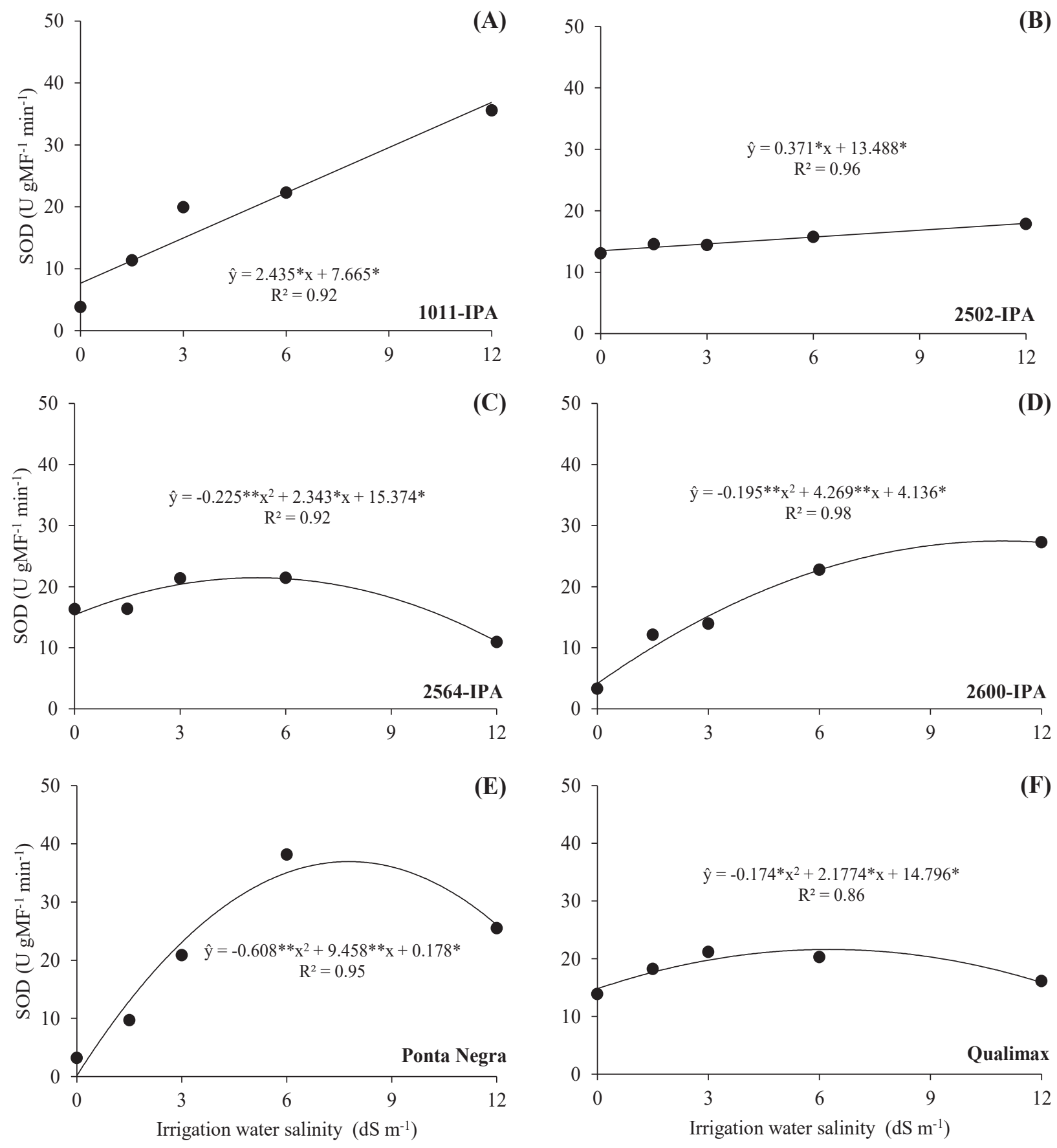

Figure 3. Activity of superoxide dismutase (SOD) in grain sorghum varieties subjected to different levels of irrigation water salinity. Significant regression coefficients with $\mathrm{p}<0.01(* *)$ and $\mathrm{p}<0.05(*)$. 
(Balla et al., 2019; Guimarães et al., 2018). The results may be related to the great genetic variability of sorghum crop, which enables different responses of the enzymatic system in each variety/genotype/cultivar.

The varieties 2502-IPA, Ponta Negra and Qualimax showed quadratic regressions for the activities of CAT and APX. For 2502-IPA, the maximum activities of CAT and APX were observed at salinity levels of 6.36 and $4.91 \mathrm{dS} \mathrm{m}^{-1}$, respectively. In the variety Ponta Negra, salinity levels of 17.3 and $5.75 \mathrm{dS} \mathrm{m}^{-1}$ promoted the highest activities of CAT and APX, respectively. The variety Qualimax showed the highest CAT activity when irrigated with ECw of 3.96 $\mathrm{dS} \mathrm{m} \mathrm{m}^{-1}$ and highest APX activity under ECw of $7.9 \mathrm{dS}$ $\mathrm{m}^{-1}$.

The genotypes of forage sorghum, CSF18 (sensitive) and CSF20 (tolerant), when subjected to salinity of up to $75 \mathrm{mM}$ of $\mathrm{NaCl}$, showed increases in SOD and CAT activities, especially CSF20. As for APX, there were different responses among the genotypes. While in the genotype CSF18 there were decreases, the genotype CSF20 showed increments in the activity of this enzyme in response to salinity (Costa et al. 2005).

In a study evaluating the sorghum genotypes "Payam" and "Sistan" cultivated in Hoagland nutrient solution containing $\mathrm{NaCl} 0,100$ and $200 \mathrm{mM}$ in a controlled environment, Heidari (2009) observed significant increases in the activities of APX, CAT and guaiacol peroxidase (GPX). Freitas et al. (2011), when evaluating the effect of salinity on the sorghum variety CSF 20, observed that there was no change in SOD and APX activities when subjected to high salinity levels (up to $8 \mathrm{dS} \mathrm{m}^{-1}$ ). However, these authors also observed a reduction of up to $37 \%$ in the enzymatic activity of CAT when salinity exceeded $4 \mathrm{dS} \mathrm{m} \mathrm{m}^{-1}$.

Reductions in enzymatic activities under high salinity levels, as observed in the present study, may be associated with the adaptability of the genetic materials evaluated when subjected to the saline condition, since it is recognized that very high salinity levels cause inhibition of a wide range of enzymes (Munns et al., 2002; Sun et al., 2019).

Associated with the maintenance of enzyme activity, the synchrony of behavioral pattern between these enzymes must be fundamental for regulating the level of ROS produced in the plant cell because, as $\mathrm{O}_{2}{ }^{-}$molecules are generated, they are dismutated to $\mathrm{H}_{2} \mathrm{O}_{2}$ by SOD and then the $\mathrm{H}_{2} \mathrm{O}_{2}$ is eliminated by the actions of CAT and APX, which converts it into water and/or oxygen. Thus, the efficiency of this interaction reduces the level of oxidative stress (Guimarães et al., 2018).

When using enzymatic variables to determine plant tolerance to abiotic stresses, it is necessary to associate changes in enzymatic activities with production parameters of the evaluated crops. In this context, plants that show enzymatic alterations without synchrony between the lines of defense (SOD - 1st line and CAT, APX - 2nd line of defense) and reduction in production can be considered sensitive to the applied stress. On the other hand, plants that either do not show alterations or show alterations with synchrony between the lines of defense associated with maintenance or increase in production can be considered tolerant.

The changes observed in physiological metabolism are reflected in the biomass production of the evaluated plants (Figure 5). The varieties 2600-IPA and Qualimax had the lowest shoot dry mass production (SDM) at virtually all salinity levels evaluated. The Qualimax variety stood out for showing the highest transpiration rate and stomatal conductance, and lowest turgor potential, which 
(A)
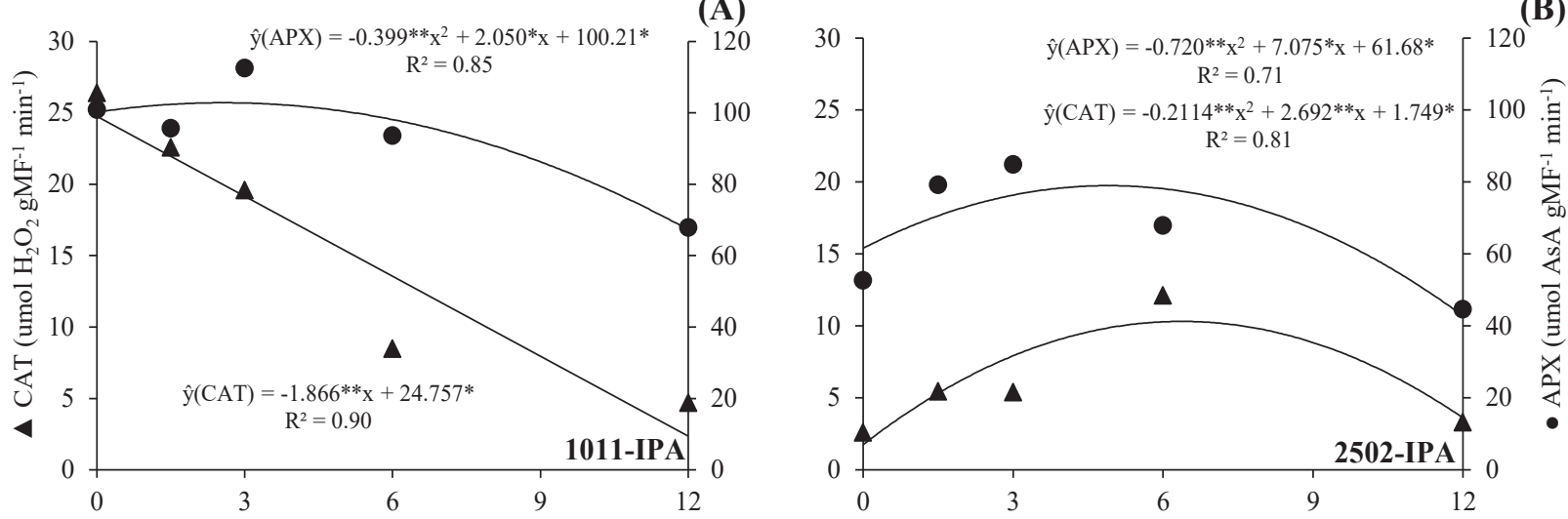

(C)
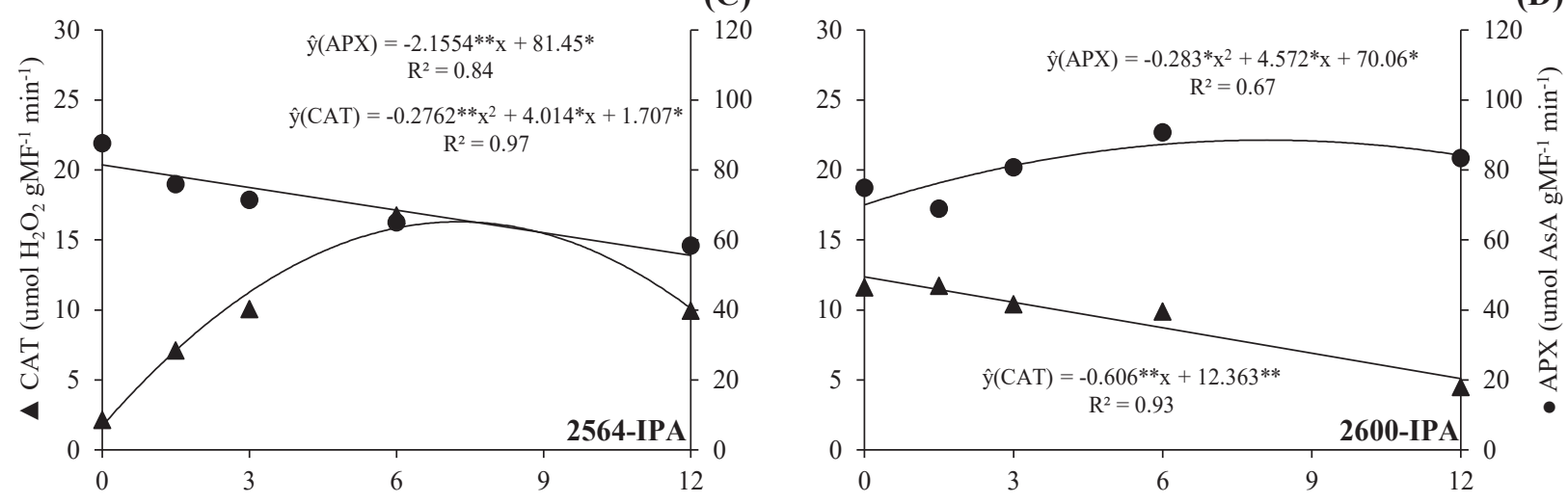

(E)
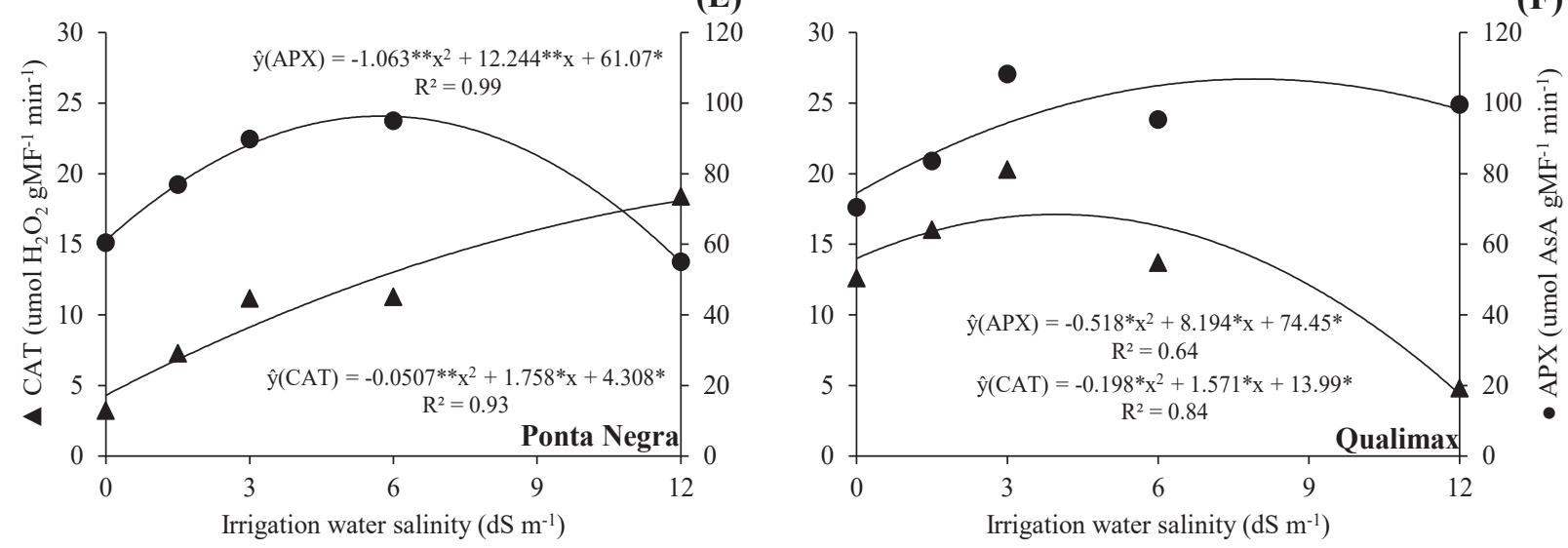

Figure 4. Activity of catalase (CAT) and ascorbate peroxidase (APX) in grain sorghum varieties subjected to different levels of irrigation water salinity. Significant regression coefficients with $\mathrm{p}<0.01(* *)$ and $\mathrm{p}<0.05(*)$. 
compromises cell elongation (Table 1) (Sampaio et al., 2014). The variety 2600-IPA, in turn, showed values numerically close to those of Qualimax with regard to transpiration rate and stomatal conductance, and the lowest relative water content. These behaviors, together with the lack of synchrony between the enzymes SOD, APX and CAT observed in these varieties, led to a lower shoot dry mass production, indicating higher sensitivity to salt stress.

The 2600-IPA variety showed increase in SOD activity, reduction in CAT activity, and a small increase in APX activity up to ECw of $8.07 \mathrm{dS} \mathrm{m}^{-1}$ as salinity increased. This type of behavior can cause damage due to $\mathrm{H}_{2} \mathrm{O}_{2}$ accumulation in the cells, as both CAT and APX are the main means of removing $\mathrm{H}_{2} \mathrm{O}_{2}$ from plant cells, converting it into $\mathrm{H}_{2} \mathrm{O}$. In the Qualimax variety, there was a small increase in SOD activity with the increase in $\mathrm{ECW}$, which may not have been sufficient to dismutate the excess of $\mathrm{O}_{2}{ }^{--}$in the cells. Similar behaviors were observed for the varieties
2502-IPA and 2564-IPA, which showed intermediate SDM values when compared to the others (Figure 5). The 1011-IPA variety showed a linear increase in SOD activity (Figure 3), accompanied by reductions in CAT and APX (Figure 4). However, it can be observed that this variety, together with Ponta Negra, obtained the highest SDM at salinity levels of 3.0 and $6.0 \mathrm{dS} \mathrm{m}^{-1}$ (Figure 5). This behavior suggests that this variety regulates ROS levels through nonenzymatic antioxidant compounds such ascorbate, glutathione, $\beta$-carotene, $\alpha$-tocopherol, among others (Barbosa et al., 2014).

The variety Ponta Negra showed, in general, higher values of SDM at virtually all salinity levels tested (Figure 5). This behavior results from the synchronism in the activity of enzymes that act against oxidative stress. For this variety, SOD and APX had their highest activity close to $7.0 \mathrm{dS} \mathrm{m}^{-1}$, evidencing the synchrony of these enzymes in the control of ROS, probably generated by photosynthesis in chloroplasts.

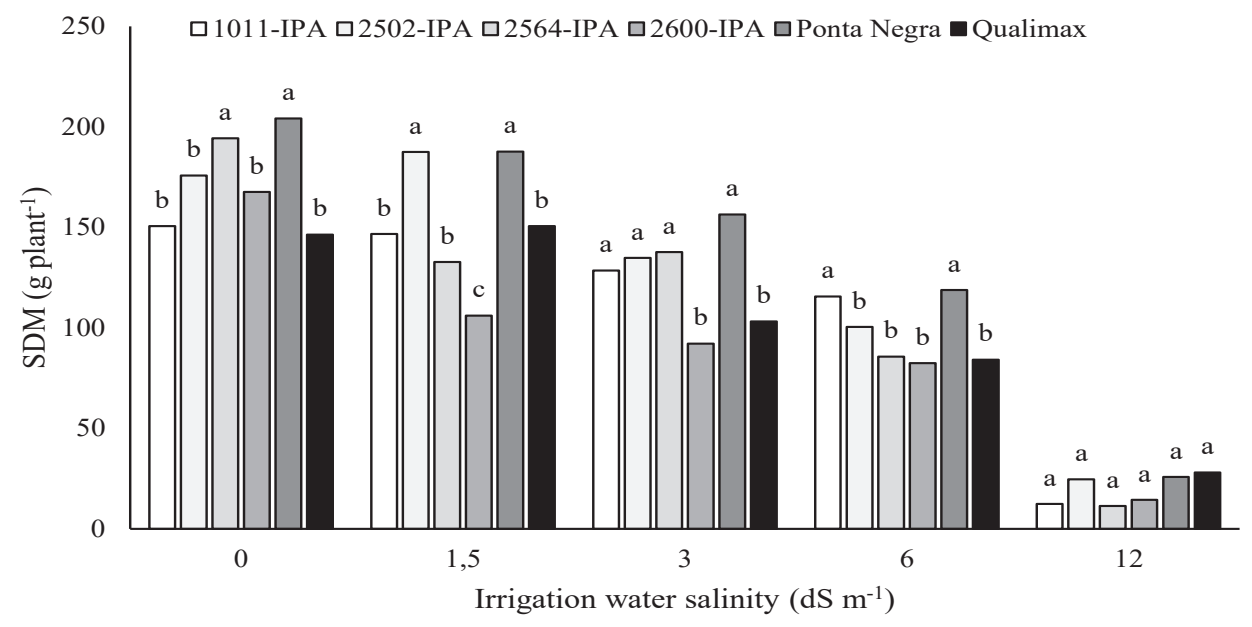

Figure 5. Averages of shoot dry mass (SDM) production of grain sorghum varieties subjected to levels of irrigation water salinity. *Columns followed by the same letter within each salinity level do not differ by ScottKnott test at $5 \%$ probability level. 
CAT, in turn, shows an increase in its activity as a function of the salt levels. It is worth pointing out that this enzyme is mainly effective at high concentrations of $\mathrm{H}_{2} \mathrm{O}_{2}(\mathrm{mM})$, so it is considered indispensable for the detoxification of ROS under severe stresses (Gill \& Tuteja, 2010).

\section{Conclusions}

Irrigation with saline water causes reduction in the water status and gas exchange of grain sorghum varieties.

The saline environment causes alterations in the antioxidative defense system in the grain sorghum varieties evaluated, and the synchronism between the enzymes SOD and APX and the increasing activity of CAT promote higher biomass production for the variety Ponta Negra at all salinity levels.

Shoot dry biomass is lower in all grain sorghum varieties when subjected to salinity level of $12.0 \mathrm{dS}$ $\mathrm{m}^{-1}$.

\section{Acknowledgments}

To the Pernambuco State Science and Technology Support Foundation - FACEPE (IBPG1556-5.03/13) for the scholarship granted and to the National Council for Scientific and Technological Development (CNPq) for the financial support.

\section{References}

AROCA, R. V.; CALBO, A. G. An automatic and portable Wiltmeter leaf turgor measurement device. Computers and Electronics in Agriculture, v. 121, p. 222-233, 2016. DOI: 10.1016/j.compag.2015.12.013.

BALLA, K.; KARSAI, I.; BÓNIS, P.; KISS, T.;
BERKI, Z.; HORVÁTH, Á.; MAYER, M.; BENCZE, S.; VEISZ, O. Heat stress responses in a large set of winter wheat cultivars (Triticum aestivum L.) depend on the timing and duration of stress. PLoS ONE, v. 14, n. 9, p. 1 - 20, 2019. DOI: 10.1371/journal. pone.0222639.

BARBOSA, M. R.; SILVA, M. M. A.; WILLADINO, L.; ULISSES, C.; CAMARA, T. R. Geração e desintoxicação enzimática de espécies reativas de oxigênio em plantas. Ciência Rural, v. 44, n. 3, p. 453-460, 2014. DOI: 10.1590/S010384782014000300011 .

BHATTACHARJEE, S. Sites of generation and physicochemical basis of formation of reactive oxygen species in plant cell. In: GUPTA, S.D. Reactive oxygen species and antioxidants in higher plants. Enfield: Science Publishers, 2010. p.1-30.

COELHO, D. S.; SIMÕES, W. L.; SALVIANO, A. M.; MESQUITA, A. C.; ALBERTO, K. C. Gas exchange and organic solutes in forage sorghum genotypes grown under different salinity levels. Revista Brasileira de Engenharia Agrícola e Ambiental, v. 22, n. 4, p. 231-236, 2018. DOI: 10.1590/1807-1929/ agriambi.v22n4p231-236.

COSTA, P. H. A.; AZEVEDO NETO, A. D.; BEZERRA, M. A.; PRISCO, J. T.; GOMES-FILHO, E. Sistema enzimático antioxidante de dois genótipos de sorgo diferindo na tolerância à salinidade. Brazilian Journal of Plant Physiology, v.17, n.4, p.353-362, 2005. DOI: 10.1590/S1677-04202005000400003.

COSTA, A. R. F. C.; COSTA, J. P. N.; MEDEIROS, J. F.; SILVA, M. V. T.; LINO, V. A. S. Desempenho 
de variedades de sorgo dupla aptidão submetidas a diferentes lâminas de irrigação com água salina. Revista Brasileira de Milho e Sorgo, v.18, n.3, p. 417-428, 2019. DOI: 10.18512/1980-6477/rbms. v18n3p417-428.

FERNÁNDEZ-GARCÍA, N.; OLMOS, E.; BARDISI, E.; GARMA, J. G.; LÓPEZ-BERENGUER, C.; RUBIO-ASENSIO, J. S. Intrinsic water use efficiency controls the adaptation to high salinity in a semi-arid adapted plant, henna (Lawsonia inermis L.). Journal of Plant Physiology, v. 171, n. 5, p. 64-75, 2014. DOI: 10.1016/j.jplph.2013.11.004.

FREIRE, J. L. O.; DIAS, T. J.; CAVALCANTE, L. J.; FERNANDES, P. D.; LIMA NETO, A. J. Rendimento quântico e trocas gasosas em maracujazeiro amarelo sob salinidade hídrica, biofertilização e cobertura morta. Revista Ciência Agronômica, v. 45, n. 1, p. 8291, 2014. DOI: 10.1590/S1806-66902014000100011.

FREITAS, V. S.; ALENCAR, N. L. M.; LACERDA, C. F.; PRISCO, J. T.; GOMES-FILHO, E. Changes in physiological and biochemical indicators associated with salt tolerance in cotton, sorghum and cowpea. African Journal of Biochemistry Research. v. 5, n. 8, p. 264-271, 2011.

GIANNOPOLITIS, C. N.; RIES, S. K. Superoxide Dismutases: I. Occurrence in Higher Plants. Plant Physiology, v. 59, n. 2, p. 309-314, 1977. DOI: 10.1104/pp.59.2.309.

GILL, S.; TUTEJA, N. Reactive oxygen species and antioxidant machinery in abiotic stress tolerance in crop plants. Plant Physiology and Biochemistry, v. 48, n. 12 , p. 909-930, 2010. DOI: 10.1016/j. plaphy.2010.08.016.
GUIMARÃES, M. J. M.; SIMÕES, W. L.; CAMARA, T. J. R.; SILVA, C. U. C.; WILlADINO, L. G. Antioxidant defenses of irrigated forage sorghum with saline aquaculture effluent. Revista Caatinga, v. 31, n. 1, p. 135-142. 2018. DOI: 10.1590/1983-21252018v3 1n116rc.

GUIMARÃES, M. J. M, SIMÕES, W. L., OLIVEIRA, A. R., ARAÚJO, G. G. L., SILVA, E. F. F., WILLADINO, L. G. Biometrics and grain yield of sorghum varieties irrigated with salt water. Revista Brasileira de Engenharia Agrícola e Ambiental. v. 23, n. 4, p. 285-290, 2019. DOI: 10.1590/1807-1929/ agriambi.v23n4p285-290.

HAVIR, E.A., MCHALE, N.A. Biochemical and developmental characterization of multiple forms of catalase in tobacco leaves. Plant Physiology, v. 84, n. 2, p. 450-455, 1987. DOI: 10.1104/pp.84.2.450.

HEIDARI, M. Antioxidant activity and osmolyte concentration of sorghum (Sorghum bicolor) and wheat (Triticum aestivum) genotypes under salinity stress. Asian Journal of Plant Sciences, v.8, n. 3, p. 240-24, 2009. DOI: 10.3923/ajps.2009.240.244.

MUNNS, R.; HUSAIN, S. RIVELLI, A. R.; JAMES, R. A.; CONDON, A. G. T.; LINDSAY, M. P.; LAGUDAH, E. S.; SCHACHTMAN, D. P.; HARE, R. A. Avenues for increasing salt tolerance of crops, and the role of physiologically based election traits. Plant and Soil, v.247, n. 1, p. 93-105, 2002. DOI: 10.1023/A:1021119414799.

NAKANO, Y., ASADA, K. Hydrogen peroxide is scavenged by ascorbate specific peroxidase in spinach chloroplast. Plant Cell Physiology, v. 22, n. 5, p. 867-880, 1981. DOI: 10.1093/oxfordjournals. 
pcp.a076232.

OLIVEIRA, W. J.; SOUZA, E. R.; CUNHA, J. C.; SILVA, E. F. F.; VELOSO, V. L. Leaf gas exchange in cowpea and $\mathrm{CO}_{2}$ efflux in soil irrigated with saline water. Revista Brasileira de Engenharia Agrícola e Ambiental, v.21, n.1, p.32-37, 2017. DOI: 10.1590/1807-1929/agriambi.v21n1p32-37.

SAMPAIO, A. H. R.; COELHO FILHO, M. A.; CALBO, A. G.; SILVA, T. C.; SANTOS, D. B.; MACHADO, M. S. Leaf and Fruit Turgor Potential in Passion Fruit Plants using Wiltmeter and Turgormeter. Journal of Agricultural Physics, v. 14, n. 1, p. 3036, 2014.

SILVA, F. L. B.; LACERDA, C. F.; NEVES, A. L. R.; SOUSA, G. G.; SOUSA, C. H. C.; FEERIRA, F. J. Irrigação com águas salinas e uso de biofertilizante bovino nas trocas gasosas e produtividade de feijãode-corda. Irriga, v. 18, n. 2, p. 304-317, 2013. DOI: 10.15809/irriga.2013v18n2p304.
SILVA, F. G.; DUTRA, W. F.; DUTRA, A. F.; OLIVEIRA, I. M.; FILGUEIRAS, L. M. B.; MELO, A. S. Trocas gasosas e fluorescência da clorofla em plantas de berinjela sob lâminas de irrigação. Revista Brasileira de Engenharia Agrícola e Ambiental, v.19, n.10, p.946-952, 2015. DOI: 10.1590/18071929/agriambi.v19n10p946-952.

SUN, J.; HE, L.; LI, T. Response of seedling growth and physiology of Sorghum bicolor (L.) Moench to saline-alkali stress. PLOS ONE, v. 14, n. 7, p. 1-10, 2019. DOI: 10.1371/journal.pone.0220340.

TABATABAEI, S. A.; ANAGHOLI, A. Effects of salinity on some characteristics of forage sorghum genotypes at germination stage. International Journal of Agriculture and Crop Sciences, v. 4, n. 14, p. 979-983, 2012.

TAIZ, L.; ZEIGER, E. Fisiologia vegetal. 5. ed. Porto Alegre: Artmed, 2013. 954 p. 